\title{
The Effect of Angiotensin II on the Blood Pressure in Humans with Hypertensive Disease *
}

\author{
Norman M. Kaplan and Jack G. Silah \\ (From the Department of Internal Medicine, the University of Texas Southwestern Medical \\ School, Dallas, Texas)
}

A reduced sensitivity to the pressor effect of exogenous angiotensin ${ }^{1}$ has been observed in dogs with increased levels of endogenous angiotensinlike activity (1). Patients with secondary hyperaldosteronism, where levels of endogenous angiotensin are thought to be elevated, also have a reduced pressor responsiveness to exogenous angiotensin, but not to $l$-norepinephrine $(2,3)$. A reduced pressor responsiveness to angiotensin might then be expected with renovascular hypertension, which is said to be associated with increased levels of circulating renin and angiotensin (4).

The pressor responses to exogenous angiotensin and, in some patients, to $l$-norepinephrine were initially examined in a variety of experimental and pathological situations where the levels of endogenous angiotensin have either been shown or are believed to be altered. Patients with various hypertensive diseases were then studied. The results suggest that the pressor responsiveness to angiotensin may be a useful clinical test for the diagnosis of renovascular hypertension.

\section{Subjects}

The clinical data are given in Table I.

Normotensive patients (Patients 1 to 18). These were healthy young adults (Patients 1 to 6 ) or convalescent patients with normal renal and hepatic function ( $\mathrm{Pa}-$ tients 7 to 18 ).

Primary aldosteronism (Patients 19 to 22). Three of the four patients had the typical clinical, laboratory, and pathological features of primary aldosteronism. The

* Submitted for publication July 29, 1963 ; accepted December 4, 1963.

Presented in part at the Seventeenth Annual Meeting of the Southern Society for Clinical Research, January 26, 1963, and published as an abstract (Clin. Res. 1963, 11, 55). This work was supported by grants from the Dallas and Texas Heart Associations and the U. S. Public Health Service.

1 Unless otherwise specified, the term angiotensin is used to designate the active octapeptide, angiotensin II. fourth was unique in that his hypertension was of a malignant nature, and he had areas of nodular hyperplasia of the adrenal cortex as well as a single adenoma (5).

Cirrhosis with ascites (Patients 23 to 28). All were chronic alcoholics and were actively accumulating ascites. Although all had derangements of hepatic function, none was acutely ill.

Essential hypertension (Patients 29 to 57) and labile hypertension (Patients 58 and 59). The diagnosis was based on the following criteria: diastolic blood pressure $90 \mathrm{~mm}$ $\mathrm{Hg}$ or higher after 2 hours of bed rest, the absence of papilledema or rapidly accelerating retinopathy, blood urea nitrogen below $30 \mathrm{mg}$ per $100 \mathrm{ml}$, and the absence of all known causes of hypertension. The diastolic blood pressure was $120 \mathrm{~mm} \mathrm{Hg}$ or higher in eight patients. All 29 patients had normal intravenous pyelograms and urinary 3-methoxy-4-hydroxymandelic acid excretion. In nine, renal arteriography was done and was normal. Two additional patients (Patients 55 and 56) had intermittent diastolic hypertension, but were studied while normotensive.

Chronic renal disease (Patients 60 to 67). The causes of the chronic renal disease on clinical grounds were: chronic pyelonephritis (Patient 60), arteriolar nephrosclerosis (Patients 61 to 63 ), chronic glomerulonephritis (Patients 64 to 66), and gouty nephritis (Patient 67). All patients had stable renal insufficiency with blood urea nitrogens above $30 \mathrm{mg}$ per $100 \mathrm{ml}$ for at least 6 months. None had edema or significant salt wastage.

Malignant hypertension (Patients 68 to 82). The patients with malignant hypertension had no known cause for their disease. The diagnosis was based on the presence of accelerating hypertension with diastolic blood pressure levels above $120 \mathrm{~mm} \mathrm{Hg}$ and bilateral papilledema. Renal arteriography was performed on five patients, and, in two, defects were visualized but not found at surgery.

Renovascular hypertension (Patients 83 to 91). Renal artery stenosis was demonstrated by arteriography and proved at surgery. Patients 83 to 88 had arteriosclerotic plaques, Patient 89 bilateral fibromuscular hyperplasia, and Patients 90 and 91 hypoplasia of one kidney but no selective lesions of the renal arteries. Relief of hypertension occurred in six of the patients including one with a hypoplastic kidney, but most are less than 6 months postoperative. Three of the patients were retested postoperatively; in two, Patients 88 and 90, the 
TABLE I

Clinical data, dose of angiotensin, and control aldosterone secretion rates for all subjects*

\begin{tabular}{|c|c|c|c|c|c|c|c|c|c|c|c|}
\hline \multirow[b]{2}{*}{ Patient } & \multirow[b]{2}{*}{ Age } & \multirow[b]{2}{*}{ Sex } & \multirow[b]{2}{*}{ Race } & \multirow{2}{*}{$\begin{array}{c}\text { Blood } \\
\text { pressure }\end{array}$} & \multirow{2}{*}{$\begin{array}{l}\text { Optic } \\
\text { fundi }\end{array}$} & \multirow[b]{2}{*}{ BUN } & \multicolumn{2}{|c|}{ Serum } & \multirow{2}{*}{\multicolumn{2}{|c|}{$\begin{array}{l}\text { Dose of angio- } \\
\text { tensin }\end{array}$}} & \multirow{2}{*}{$\begin{array}{l}\text { Pressor } \\
\text { effect }\end{array}$} \\
\hline & & & & & & & $\mathrm{Na}$ & $\mathbf{K}$ & & & \\
\hline & & & & & grade & $\mathrm{mg} / 100 \mathrm{ml}$ & & & $\mu g / \min$ & $\underset{\min }{\operatorname{m\mu g} / \mathrm{kg} /}$ & \\
\hline Normotens & & & & & & & & & & & \\
\hline 1 & 28 & $\mathbf{M}$ & W & $115 / 65$ & 0 & 14 & 138 & 4.1 & 0.58 & 7.8 & + \\
\hline 2 & 24 & $\mathbf{M}$ & W & $120 / 75$ & 0 & 15 & 140 & 4.5 & 0.49 & 6.9 & + \\
\hline 3 & 22 & $\mathbf{M}$ & W & $120 / 80$ & 0 & 12 & 140 & 3.9 & 0.50 & 6.0 & + \\
\hline 4 & 30 & $\mathbf{M}$ & $\mathbf{W}$ & $115 / 70$ & 0 & 16 & 138 & 4.0 & 0.58 & 7.8 & + \\
\hline 5 & 29 & $\mathbf{M}$ & W & $120 / 65$ & 0 & 14 & 139 & 4.1 & 0.59 & 7.9 & + \\
\hline 6 & 29 & $\mathbf{M}$ & W & $100 / 70$ & 0 & 14 & 140 & 3.8 & 0.56 & 9.3 & + \\
\hline 7 & 33 & $\mathrm{~F}$ & $\mathbf{N}$ & $100 / 70$ & 0 & 13 & 138 & 4.0 & 0.49 & 9.0 & + \\
\hline 8 & 24 & $\mathrm{~F}$ & $\mathrm{~N}$ & $100 / 70$ & 0 & 13 & 136 & 3.9 & 0.34 & 6.7 & + \\
\hline 9 & 55 & $\mathbf{F}$ & W & $100 / 60$ & 0 & 12 & 141 & 4.8 & 0.11 & 6.7 & + \\
\hline 10 & 28 & $\mathrm{~F}$ & W & $95 / 70$ & 0 & 16 & 139 & 4.0 & 0.76 & 11.4 & + \\
\hline 11 & 20 & $\mathrm{~F}$ & $\mathrm{~N}$ & $130 / 85$ & 0 & 8 & 140 & 4.1 & 0.43 & 6.6 & + \\
\hline 12 & 58 & $\mathrm{M}$ & W & $105 / 75$ & 0 & 12 & 138 & 4.3 & 0.40 & 6.3 & + \\
\hline 13 & 48 & $\mathrm{~F}$ & $\mathrm{~N}$ & $110 / 60$ & 0 & 15 & 138 & 4.1 & 0.43 & 7.2 & + \\
\hline 14 & 33 & $F$ & $\mathrm{~N}$ & $115 / 60$ & 0 & 10 & 140 & 4.2 & 0.44 & 6.8 & + \\
\hline 15 & 26 & M & W & $100 / 60$ & 0 & 9 & 138 & 3.8 & 0.32 & 7.0 & + \\
\hline 16 & 15 & $\mathbf{M}$ & W & $130 / 80$ & 0 & 11 & 142 & 4.2 & 0.42 & 6.0 & + \\
\hline 17 & 30 & $F$ & $\mathrm{~N}$ & $115 / 65$ & 0 & 12 & 142 & 3.6 & 0.44 & 7.6 & + \\
\hline 18 & 21 & $\mathbf{M}$ & $\mathrm{N}$ & $120 / 65$ & 0 & 12 & 137 & 4.0 & 0.36 & 6.5 & + \\
\hline Primary al & oster & & & & & & & & & & \\
\hline 19 & 49 & $\mathbf{M}$ & W & $210 / 120$ & 2 & 17 & 145 & 2.8 & 0.20 & 3.2 & + \\
\hline 20 & 34 & $\mathrm{~F}$ & W & $150 / 100$ & 1 & 18 & 137 & 2.6 & 0.13 & 2.1 & + \\
\hline 21 & 48 & $\mathbf{F}$ & W & $175 / 100$ & 1 & 12 & 149 & 2.6 & 0.16 & 2.5 & + \\
\hline 22 & 42 & $\mathbf{M}$ & W & $190 / 115$ & 4 & 17 & 145 & 2.8 & 0.50 & 5.3 & + \\
\hline Cirrhosis w & h asc & & & & & & & & & & \\
\hline 23 & 37 & $\mathbf{M}$ & W & $120 / 60$ & 0 & 22 & 125 & 3.5 & 1.38 & 19.0 & + \\
\hline 24 & 61 & $\mathbf{M}$ & W & $185 / 100$ & 2 & 21 & 135 & 4.0 & 1.65 & 20.4 & - \\
\hline 25 & 40 & $\mathrm{~F}$ & W & $145 / 80$ & 0 & 6 & 138 & 2.8 & 2.56 & 20.2 & - \\
\hline 26 & 40 & $\mathrm{M}$ & $\mathrm{W}$ & $125 / 90$ & 1 & 12 & 139 & 4.0 & 0.7 & 13.8 & + \\
\hline 27 & 42 & $\mathbf{M}$ & $\mathbf{W}$ & $135 / 85$ & 0 & 14 & 133 & 3.8 & 0.34 & 6.8 & + \\
\hline 28 & 47 & $\mathbf{M}$ & W & $155 / 90$ & 1 & 29 & 132 & 2.9 & 2.62 & 20.8 & - \\
\hline Essential $h$ & perte & & & & & & & & & & \\
\hline 29 & 62 & $\mathbf{M}$ & $\mathrm{N}$ & $200 / 120$ & 2 & 15 & 143 & 4.0 & 0.25 & 3.1 & + \\
\hline 30 & 38 & $\mathrm{~F}$ & $\mathrm{~N}$ & $140 / 90$ & 1 & 7 & 143 & 4.0 & 0.24 & 3.1 & + \\
\hline 31 & 48 & $\mathrm{~F}$ & $\mathrm{~N}$ & $170 / 100$ & 2 & 12 & 137 & 4.3 & 0.11 & 1.6 & + \\
\hline 32 & 36 & $\mathrm{~F}$ & $\mathbf{W}$ & $160 / 100$ & 0 & 16 & 137 & 4.4 & 0.10 & 1.6 & + \\
\hline 33 & 59 & $\mathrm{~F}$ & $\mathbf{W}$ & $185 / 110$ & 2 & 14 & 133 & 5.0 & 0.13 & 3.2 & + \\
\hline 34 & 65 & $\mathrm{~F}$ & $\mathrm{~N}$ & $140 / 90$ & 1 & 23 & 141 & 4.3 & 0.19 & 1.9 & + \\
\hline 35 & 46 & $\mathrm{~F}$ & $N$ & $180 / 120$ & 3 & 18 & 142 & 4.4 & 0.26 & 3.0 & + \\
\hline 36 & 44 & $\mathrm{M}$ & $\mathrm{N}$ & $175 / 100$ & 2 & 23 & 138 & 4.8 & 0.19 & 2.5 & + \\
\hline $\begin{array}{l}30 \\
37\end{array}$ & $\begin{array}{l}44 \\
22\end{array}$ & $\mathrm{~F}$ & $\mathrm{~N}$ & $140 / 100$ & 1 & 11 & 138 & 4.2 & 0.28 & 4.0 & + \\
\hline 38 & 40 & $\mathrm{~F}$ & $\mathrm{~N}$ & $160 / 90$ & 1 & 14 & 135 & 4.1 & 0.15 & 2.9 & + \\
\hline 39 & 25 & $\mathrm{~F}$ & $\mathrm{~N}$ & $150 / 100$ & 0 & 12 & 139 & 3.5 & 0.15 & 2.2 & + \\
\hline 40 & 38 & $\mathrm{~F}$ & $N$ & $165 / 100$ & 1 & 13 & 140 & 4.9 & 0.07 & 1.1 & + \\
\hline 41 & 37 & $\mathrm{~F}$ & W & $165 / 100$ & 1 & 13 & 140 & 4.2 & 0.17 & 2.8 & + \\
\hline 42 & 29 & $\mathrm{~F}$ & $\mathrm{~N}$ & $185 / 105$ & 2 & 16 & 138 & 3.8 & 0.19 & 2.3 & + \\
\hline 43 & 20 & $\mathrm{~F}$ & $\mathrm{~N}$ & $205 / 135$ & 3 & 10 & 141 & 3.8 & 0.49 & 5.0 & + \\
\hline 44 & 45 & $\mathrm{~F}$ & $N$ & $245 / 130$ & 2 & 18 & 142 & 3.5 & 0.15 & 2.0 & + \\
\hline 45 & 36 & $\mathrm{~F}$ & W & $150 / 110$ & 1 & 12 & 140 & 4.2 & 0.28 & 3.8 & + \\
\hline 46 & 35 & $\mathbf{M}$ & $\mathbf{W}$ & $145 / 100$ & 1 & 15 & 142 & 4.5 & 0.24 & 5.0 & + \\
\hline 47 & 46 & $\mathbf{M}$ & W & $150 / 90$ & 1 & 12 & 137 & 3.8 & 0.36 & 4.0 & + \\
\hline 48 & 31 & $\mathrm{~F}$ & $\mathrm{~N}$ & $240 / 140$ & 3 & 28 & 140 & 2.6 & 0.32 & 4.6 & + \\
\hline $\begin{array}{l}40 \\
49\end{array}$ & $\begin{array}{l}51 \\
33\end{array}$ & $\mathrm{~F}$ & $\mathrm{~N}$ & $160 / 110$ & 2 & 16 & 136 & 3.8 & 0.33 & 4.6 & + \\
\hline 50 & 40 & $\mathbf{M}$ & W & $150 / 100$ & 0 & 12 & 139 & 3.5 & 0.14 & 1.4 & + \\
\hline 51 & $\begin{array}{l}\mathbf{4 0} \\
37\end{array}$ & $\mathrm{~F}$ & W & $160 / 110$ & 1 & 15 & 138 & 4.1 & 0.30 & 3.8 & + \\
\hline 52 & 42 & $\mathrm{M}$ & W & $160 / 105$ & 1 & 14 & 141 & 4.1 & 0.32 & $\begin{array}{l}3.0 \\
4.0\end{array}$ & + \\
\hline 53 & 22 & $\mathrm{~F}$ & $\mathrm{~N}$ & $150 / 100$ & 1 & 8 & 143 & 4.5 & 0.12 & 1.8 & + \\
\hline 54 & 62 & $\mathrm{~F}$ & W & $205 / 155$ & 2 & 24 & 139 & 4.0 & 0.18 & 3.0 & + \\
\hline 55 & 30 & $\mathrm{~F}$ & $\mathrm{~N}$ & $165 / 105$ & 0 & 14 & 138 & 4.0 & 0.24 & 3.7 & + \\
\hline 56 & 42 & M & $\mathrm{W}$ & $165 / 120$ & 1 & 12 & 142 & 3.6 & 0.33 & 3.4 & + \\
\hline 57 & 31 & $\mathrm{~F}$ & $\mathrm{~N}$ & $180 / 140$ & 2 & 11 & 138 & 4.4 & 0.36 & 4.0 & + \\
\hline 58 & 47 & $\mathrm{~F}$ & $\mathrm{~N}$ & $110 / 70$ & 0 & 8 & 140 & 4.0 & 0.22 & 2.4 & + \\
\hline 59 & 40 & $\mathrm{~F}$ & $\mathbf{W}$ & $140 / 80$ & 0 & 14 & 1.37 & 3.8 & 0.22 & 4.1 & + \\
\hline
\end{tabular}

* Optic fundi, grades 1-4, Keith-Wagner classification; BUN, blood urea nitrogen. 
EFFECT OF ANGIOTENSIN ON BLOOD PRESSURE IN HYPERTENSIVE DISEASES

TABLE I-(Continued)

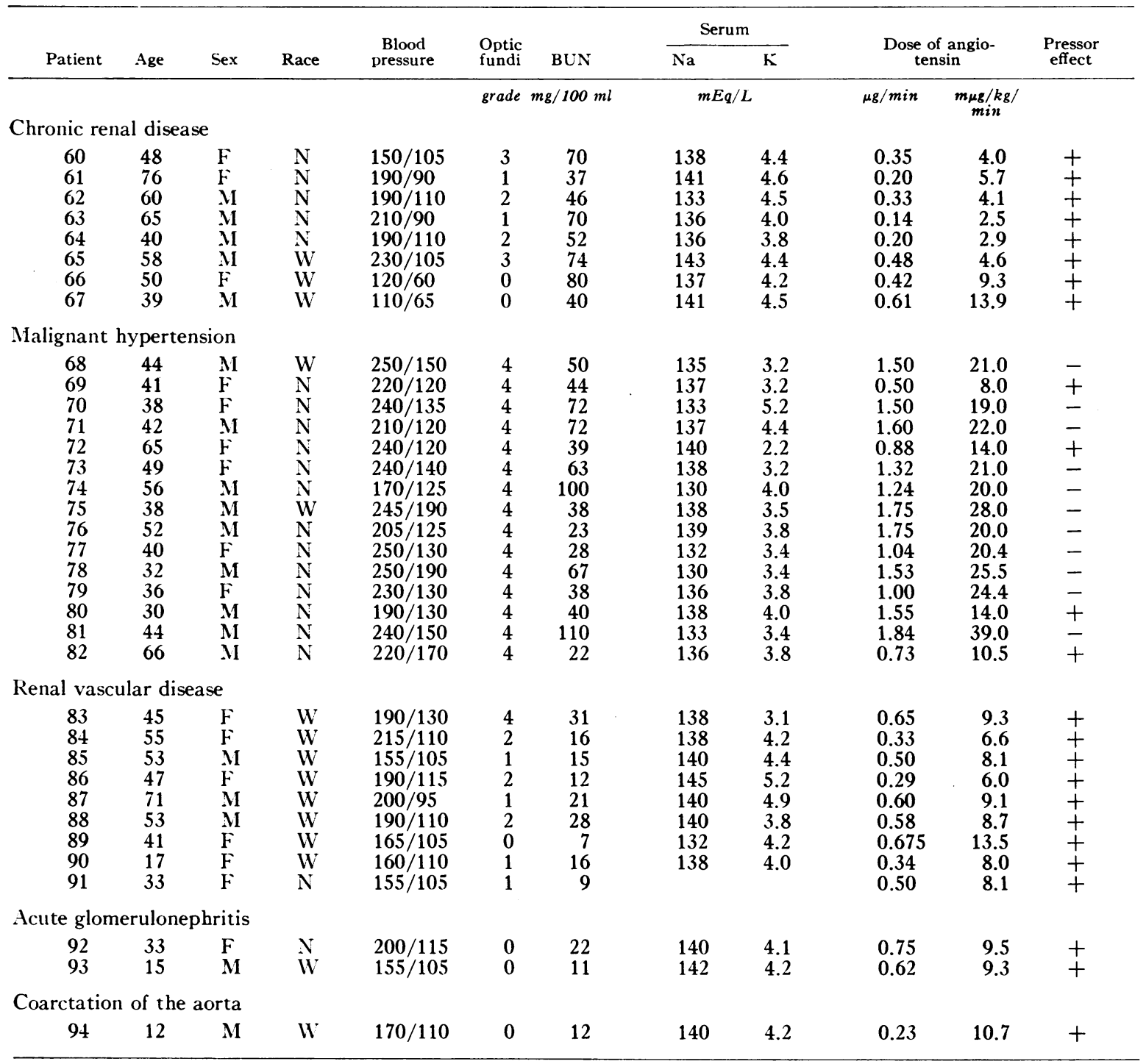

blood pressure was normal ; in one, Patient 89 , the blood pressure remained high. The hypertension was of a malignant nature only in Patient 83.

Acute glomerulonephritis (Patients 92 and 93). Both had the typical clinical and pathological features of poststreptococcal acute nephritis. They were studied in the early course of the disease while hypertensive and later after complete recovery while normotensive.

Coarctation of the aorta (Patient 94). The patient was a 12-year-old boy with postductal coarctation. The initial study was done preoperatively, the second study was done 8 days after surgical repair when the blood pressure in the arms had fallen to $150 / 80$.

\section{Test procedure}

For at least 4 days before the infusion study, all patients received approximately $100 \mathrm{mEq}$ of sodium daily, about $15 \mathrm{mEq}$ from the diet and $85 \mathrm{mEq}$ as added sodium chloride. With the patient supine, an infusion of $5 \%$ glucose in water was begun and continued until the blood pressure, measured with a sphygmomonometer, was stable for at least 30 minutes. Without disturbing the patient, the infusion was then changed to one containing $0.2 \mu \mathrm{g}$ of angiotensin 2 in each $\mathrm{ml}$ of $5 \%$ glucose in water. This was begun at a rate of 4 to 6 drops per minute, with a constant infusion pump. The rate of infusion was progressively increased every 10 to $15 \mathrm{~min}$ utes until either a $20 \mathrm{~mm} \mathrm{Hg}$ rise in diastolic blood pressure occurred or a level of $20 \mathrm{~m} \mu \mathrm{g}$ of angiotensin per kg body weight per minute was reached. The "pressor dose" of angiotensin was the amount required to produce a $20 \mathrm{~mm} \mathrm{Hg}$ rise of the diastolic blood pressure

2 Hypertensin, Ciba Pharmaceutical Co., Summit, N. J. 
and was expressed on the basis of millimicrograms per kilogram body weight per minute. $l$-Norepinephrine was infused in an identical fashion, either before or after the angiotensin infusion, at a concentration of $2.0 \mu \mathrm{g}$ per $\mathrm{ml}$.

The responses to angiotensin and $l$-norepinephrine were re-examined in certain subjects after the following manipulations: 1) a $15-\mathrm{mEq}$ sodium diet for 4 days, 2) chlorothiazide, $500 \mathrm{mg}$ twice daily for 4 to 7 days, 3) ammonium chloride, $5 \mathrm{~g}$ for 2 days, $10 \mathrm{~g}$ for 2 days, and then $15 \mathrm{~g}$ for 2 days, or 4 ) within 30 minutes after the intravenous infusion of normal saline, $250 \mathrm{ml}$ in 30 minutes in four normotensive subjects, 250 to $1,000 \mathrm{ml}$ in 1 to 5 hours in 11 subjects previously given chlorothiazide, 250 or $500 \mathrm{ml}$ in 1 or 2 hours in two subjects previously on a $15-\mathrm{mEq}$ sodium diet for 4 days.

To assess the reproducibility of the pressor response to angiotensin, infusions were repeated after 3 to 22 days in eight subjects, four with normal blood pressure and four with essential hypertension. The pressor doses agreed within $\pm 1.0 \mathrm{~m} \mu \mathrm{g}$ per $\mathrm{kg}$ per minute in seven of the eight repeat tests; it was $2.3 \mathrm{~m} \mu \mathrm{g}$ per $\mathrm{kg}$ per minute lower in the other.

Statistical evaluation was by the $t$ test (6). The values are expressed as the mean \pm standard deviation.

\section{Results}

\section{Initial studies on the pressor response to angio- tensin}

The amount of angiotensin required to produce a $20 \mathrm{~mm} \mathrm{Hg}$ rise of the diastolic blood pressure is given in Table I and plotted in Figure 1. Subjects who did not have a $20 \mathrm{~mm} \mathrm{Hg}$ rise with

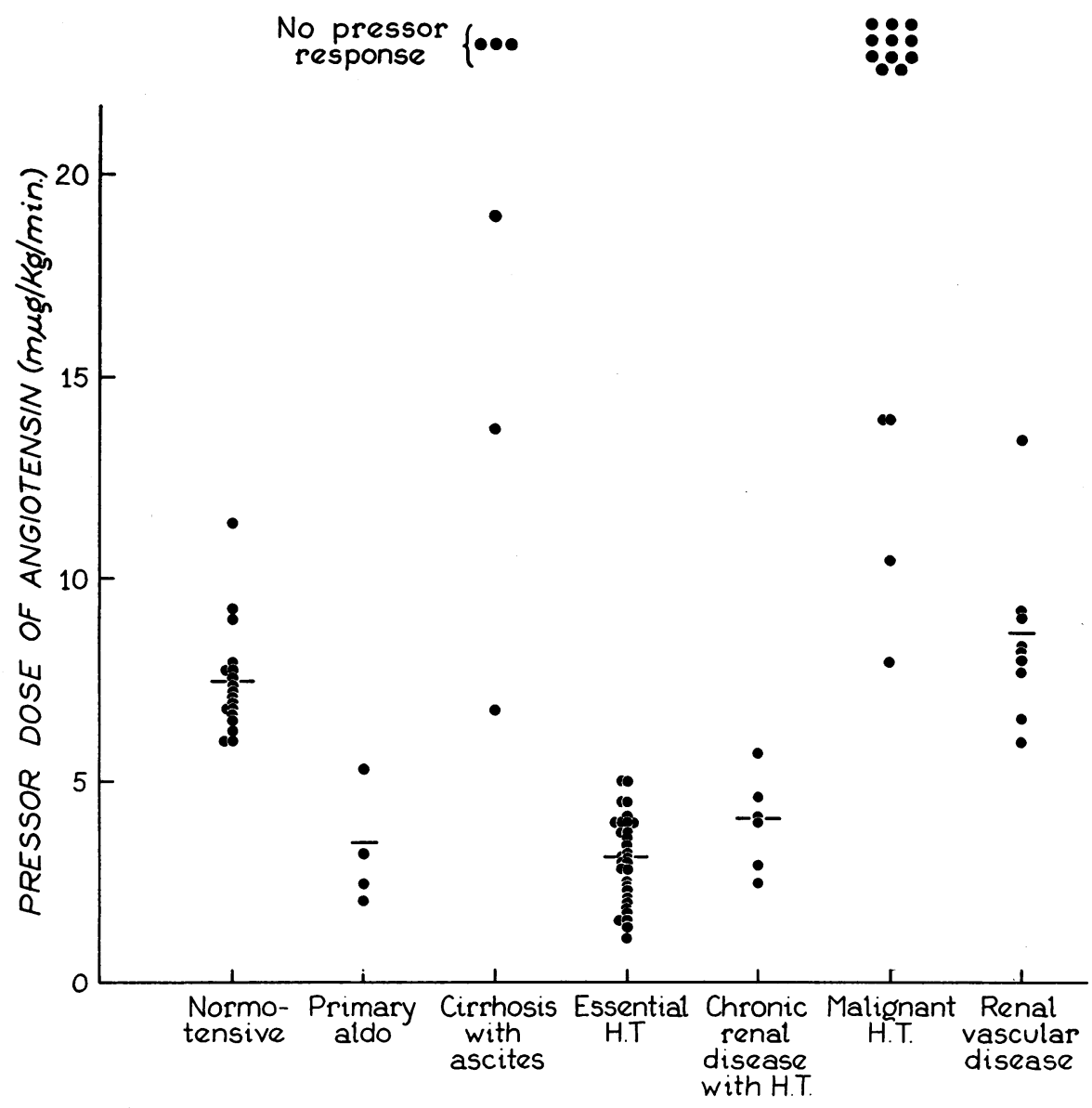

Fig. 1. Amount of ANGiotensin in millimicrograms per KILOgRam Body Weight PER MINUTE REQUiRED TO GIVE A $20 \mathrm{Mm}$ Hg RISE IN DIASTOLIC BLOOD PRESSURE IN ALL PATIENTS, GROUPED ACCORDING TO DIAGNosis. Patients who did not have this pressor response with $20 \mathrm{~m} \mu \mathrm{g}$ per $\mathrm{kg}$ per minute are plotted under "no pressor response." The mean dose for each group in which all patients were responsive is shown as the bar. Aldo = aldosteronism ; H.T. $=$ hypertension. 


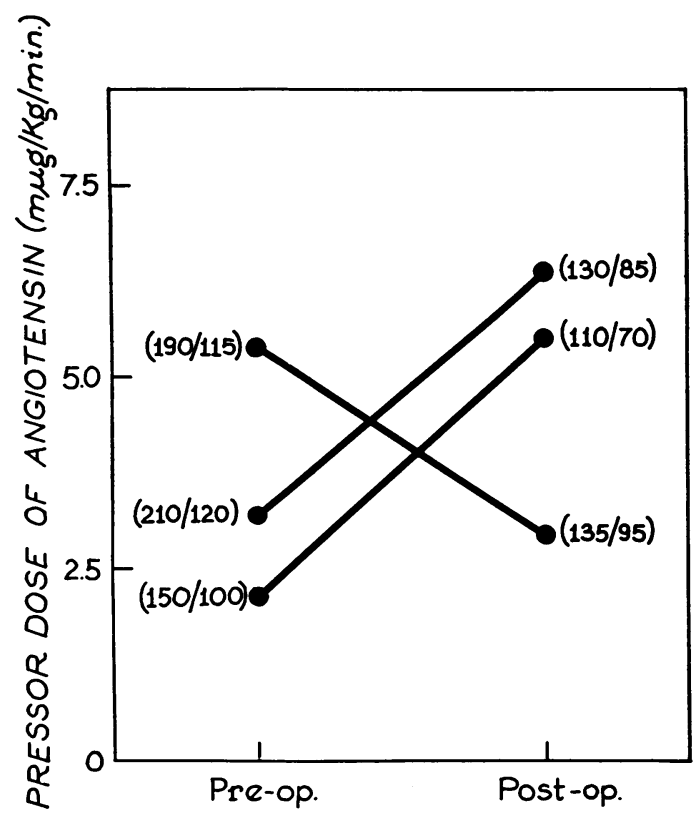

Fig. 2. PRessor dose of angiotensin and the blood PRESSCRE BEFORE AND AFTER REMOVAL OF ADRENAL ADENOMAS IN THREE PATIENTS WITH PRIMARY ALDOSTERONISM.

$20 \mathrm{~m} \mu \mathrm{g}$ of angiotensin per $\mathrm{kg}$ body weight per minute are plotted as "no pressor response."

Tests were initially performed on normotensive subjects, then on patients with primary aldosteronism or normal subjects given infusions of saline who might be expected to have low levels of circulating angiotensin, and then on patients accumulating ascites because of cirrhosis or in patients deprived or depleted of sodium who might be expected to have high levels.

Normotensize patients. The mean pressor dose of angiotensin II was $7.4 \pm 1.3 \mathrm{~m} \mu \mathrm{g}$ per $\mathrm{kg}$ per minute, with a range of 6.0 to $11.4 \mathrm{~m} \mu \mathrm{g}$ per $\mathrm{kg}$ per minute.

Primary aldosteronism. The mean pressor dose for the four patients was only $3.3 \pm 1.4 \mathrm{~m} \mu \mathrm{g}$ per $\mathrm{kg}$ per minute, significantly less than for the normotensive group $(p=<0.001)$. The pressor dose in Patient 22, who had malignant hypertension in association with primary aldosteronism, was the highest of the group, but still less than that required for any of the normotensive subjects. The response to angiotensin II was reexamined after removal of the adrenal adenoma in three of the four patients with primary aldosteronism (Figure 2). The pressor dose increased to levels seen in the normotensive group in $\mathrm{Pa}$ - tients 19 and 20, who became normotensive. In Patient 22, whose hypertension persisted though at a much milder level, the pressor dose fell to $2.9 \mathrm{~m} \mu \mathrm{g}$ per $\mathrm{kg}$ per minute, a value within the range subsequently noted for patients with essential hypertension.

After saline infusion. The pressor dose of angiotensin fell in all four normotensive subjects after the intravenous infusion of $250 \mathrm{ml}$ normal saline over a 30-minute interval (Figure 3 ).

Cirrhosis with ascites. Five of the six patients with cirrhosis who were actively accumulating ascites were resistant to the pressor effect of angiotensin. Three of the patients failed to respond to the highest dose of angiotensin used; two required amounts greater than any of the normotensive group, and the other responded to $6.8 \mathrm{~m} \mu \mathrm{g}$ per $\mathrm{kg}$ per minute.

After sodium deprivation or depletion. Both normotensive and hypertensive subjects were restudied after restriction of sodium intake for 4 days or the administration of chlorothiazide for 7 days (Table II). The blood pressure was little affected by either maneuver. The amount of angiotensin required to obtain a pressor response increased in all 12 subjects. Nine of these 12 subjects were then given an intravenous infusion of

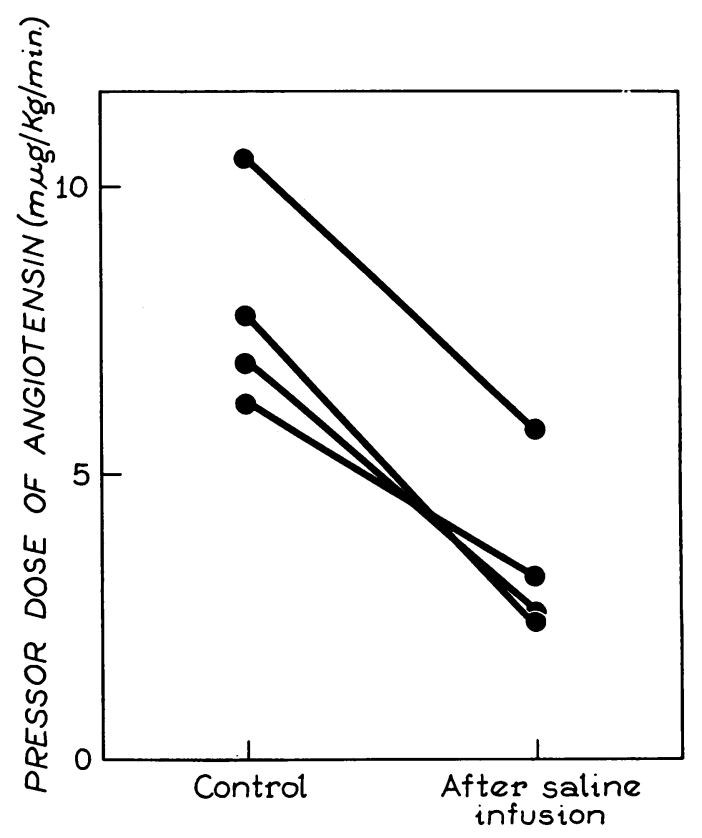

Fig. 3. Changes in the PRESSOR DOSE OF ANGIOTENSIN IN NORMAL SUBJECTS GIVEN INFUSIONS OF SALINE. 


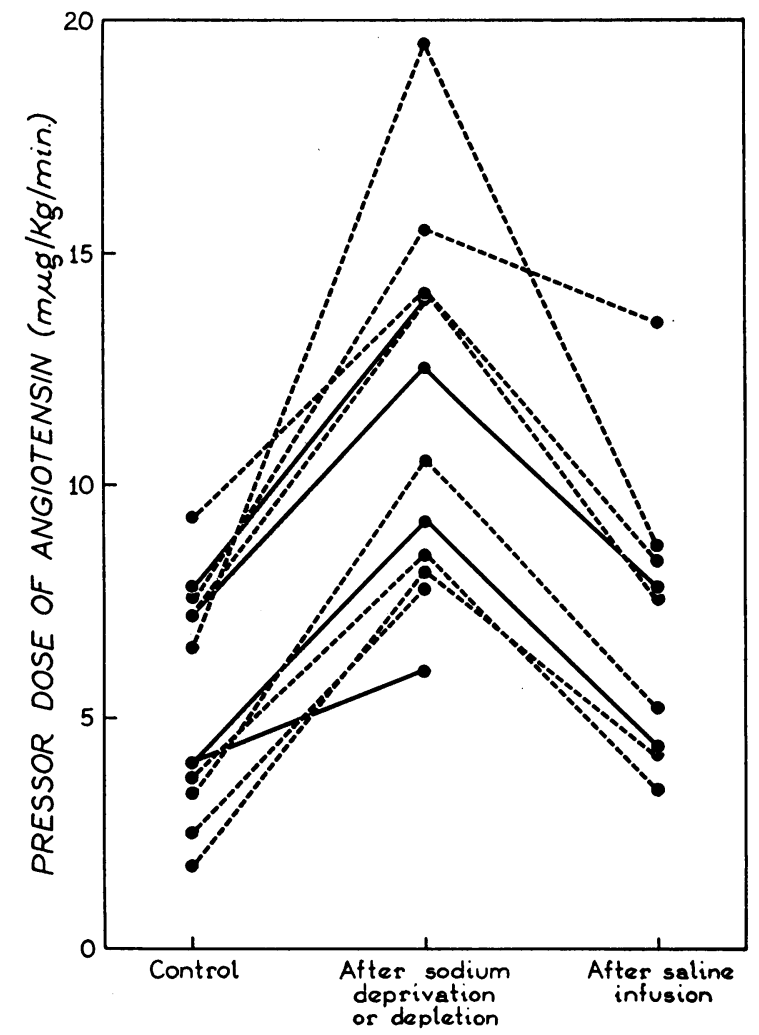

Fig. 4. Changes in the PRESSOR DOSE OF ANGIOTENSIN in Patients after SALT Deprivation (SOLID liNes), OR DEPLETION (BROKEN LINES), AND AGAIN AFTER THE INFUSION OF SALINE.

normal saline, and the angiotensin test was repeated. The pressor dose of angiotensin fell in all nine, in most back to or near the control level (Figure 4).

\section{The pressor response to angiotensin in patients with hypertension}

Angiotensin infusion tests were next performed on patients with various hypertensive diseases (Table I and Figure 1).

The mean pressor dose of angiotensin for the patients with essential hypertension was $3.1 \pm 1.1$ $\mathrm{m} \mu \mathrm{g}$ per $\mathrm{kg}$ per minute, and for the patients with hypertension in association with chronic renal parenchymal disease it was $4.0 \pm 1.1 \mathrm{~m} \mu \mathrm{g}$ per $\mathrm{kg}$ per minute, both significantly less than that required for the normotensive patients $(p=$ $<0.001)$. This heightened sensitivity to angiotensin was noted in the eight patients with essential hypertension who had diastolic levels of $120 \mathrm{~mm} \mathrm{Hg}$ or greater.
On the other hand, 13 of 15 patients with malignant hypertension were more resistant to the pressor effect of angiotensin than were the normotensive subjects, and $11 \mathrm{did}$ not respond to 20 $\mathrm{m} \mu \mathrm{g}$ per $\mathrm{kg}$ per minute (Table I and Figure 1). All 15 required more angiotensin than did any of the patients with essential hypertension.

As shown in Table I and Figure 1, the pressor dose of all the patients with renovascular hypertension or with hypertension caused by acute glomerulonephritis or coarctation of the aorta was greater than that of any of the patients with essential hypertension. The difference between the mean pressor dose of the patients with essential hypertension $(3.1 \pm 1.1 \mathrm{~m} \mu \mathrm{g}$ per $\mathrm{kg}$ per minute) and the patients with renovascular hypertension $(8.6 \pm 2.1 \mathrm{~m} \mu \mathrm{g}$ per $\mathrm{kg}$ per minute) was highly significant $(\mathrm{p}=<0.001)$.

After surgical relief of the hypertension or after recovery from acute glomerulonephritis, less angiotensin was required for a pressor response (Figure 5). Patient 89, whose blood pressure remained elevated after an attempt at relief of stenosis due to bilateral fibromuscular hyperplasia, required the same amount of angiotensin for a pressor response after surgery.

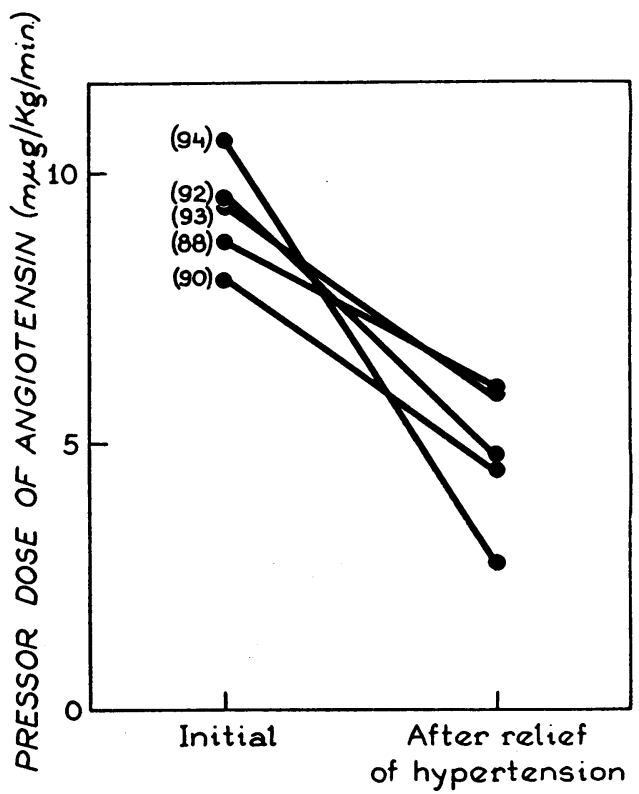

Fig. 5. Changes in the PRESSOR dose of angiotensin IN PATIENTS AFTER RELIEF OF HYPERTENSION DUE TO RENOVASCUlar Disease (PATIENTS 88 AND 90), ACUTE GLOMERUlONePhritis (Patients 92 and 93), OR COARCtation of the aorta (Patient 94). 
TABLE II

The effect of sodium deprivation or depletion and saline infusion

\begin{tabular}{|c|c|c|c|c|c|c|c|c|c|}
\hline \multirow[b]{2}{*}{ Patient } & \multicolumn{2}{|c|}{ Control } & \multicolumn{3}{|c|}{ Sodium deprivation or depletion } & \multicolumn{4}{|c|}{ Saline infusion } \\
\hline & $\begin{array}{c}\text { Blood } \\
\text { pressure }\end{array}$ & $\begin{array}{c}\text { Pressor } \\
\text { dose }\end{array}$ & $\begin{array}{c}\text { Weight } \\
\text { loss }\end{array}$ & $\begin{array}{c}\text { Blood } \\
\text { pressure }\end{array}$ & $\begin{array}{c}\text { Pressor } \\
\text { dose }\end{array}$ & Amount & Interval & $\begin{array}{c}\text { Blood } \\
\text { pressure }\end{array}$ & $\begin{array}{c}\text { Pressor } \\
\text { dose }\end{array}$ \\
\hline & & $\underset{\min }{\operatorname{m\mu g} / \mathrm{kg} /}$ & $l b s$ & & $\underset{\min }{m \mu g / k g /}$ & $m l$ & $\min$ & & $\underset{\min }{m \mu g / k g /}$ \\
\hline \multicolumn{10}{|c|}{ Sodium deprivation- $-\mathrm{Na}, 15 \mathrm{mEq}$ in diet for 4 days } \\
\hline $\begin{array}{r}4 \\
13 \\
37 \\
52\end{array}$ & $\begin{array}{l}115 / 70 \\
110 / 60 \\
140 / 100 \\
160 / 105\end{array}$ & $\begin{array}{l}7.8 \\
7.2 \\
4.0 \\
4.0\end{array}$ & $\begin{array}{l}2.6 \\
1.8 \\
2.2 \\
0.6\end{array}$ & $\begin{array}{l}115 / 70 \\
110 / 60 \\
135 / 95 \\
170 / 110\end{array}$ & $\begin{array}{r}14.0 \\
12.5 \\
9.2 \\
6.0\end{array}$ & $\begin{array}{l}500 \\
250\end{array}$ & $\begin{array}{r}120 \\
60\end{array}$ & $\begin{array}{l}110 / 60 \\
140 / 100\end{array}$ & $\begin{array}{l}7.8 \\
4.3\end{array}$ \\
\hline \multicolumn{10}{|c|}{ Sodium depletion-chlorothiazide, $1 \mathrm{~g}$ daily for 7 days } \\
\hline $\begin{array}{r}6 \\
13 \\
17 \\
18 \\
36 \\
53 \\
55 \\
56\end{array}$ & $\begin{array}{l}100 / 70 \\
110 / 60 \\
115 / 65 \\
120 / 65 \\
175 / 100 \\
150 / 100 \\
165 / 105 \\
165 / 120\end{array}$ & $\begin{array}{l}9.3 \\
7.2 \\
7.6 \\
6.5 \\
2.5 \\
1.8 \\
3.7 \\
3.4\end{array}$ & $\begin{array}{l}2.0 \\
4.5 \\
2.2 \\
4.0 \\
2.8 \\
5.5 \\
9.0 \\
3.0\end{array}$ & $\begin{array}{l}100 / 70 \\
110 / 60 \\
115 / 70 \\
115 / 70 \\
170 / 95 \\
130 / 90 \\
115 / 95 \\
190 / 125\end{array}$ & $\begin{array}{r}14.1 \\
14.1 \\
15.5 \\
19.6 \\
7.8 \\
8.2 \\
8.5 \\
10.5\end{array}$ & $\begin{array}{r}250 \\
1,000 \\
1,000 \\
500\end{array}$ & $\begin{array}{r}60 \\
90 \\
120 \\
300\end{array}$ & $\begin{array}{l}100 / 70 \\
115 / 70 \\
115 / 70 \\
110 / 60 \\
\\
150 / 100 \\
115 / 90 \\
185 / 130\end{array}$ & $\begin{array}{r}8.4 \\
7.3 \\
13.5 \\
8.7\end{array}$ \\
\hline
\end{tabular}

The effect of renal insufficiency and metabolic acidosis upon the pressor response to angiotensin

The presence of renal insufficiency had little effect on the pressor response to angiotensin. As noted above, those patients with hypertension in association with renal insufficiency were almost as sensitive to angiotensin as were patients with essential hypertension and normal renal function. Moreover, the pressor doses in Patients 63 and 64 who had renal insufficiency and normal blood pressure were similar to those of the normal subjects (Table I).

Tests were repeated in seven patients with metabolic acidosis, induced with ammonium chloride in four with normal renal function and uncovered by withdrawal of alkalinizing therapy (Shohl's solution) in three with chronic renal insufficiency (Table III). Arterial $\mathrm{pH}$ was 7.33 or below in all patients before the repeat tests. Only two of the patients had a change in the pressor dose of angiotensin greater than $1.0 \mathrm{~m} \mu \mathrm{g}$ per $\mathrm{kg}$ per minute; in one there was a change of 1.4 , in the other, 1.5 .

In all patients in the entire study, there was no correlation between the responsiveness to angiotensin and the initial level of blood pressure, the blood urea nitrogen, the serum sodium or potassium, or the arterial blood $\mathrm{pH}$.

TABLE III

The effect of metabolic acidosis

\begin{tabular}{|c|c|c|c|c|c|c|}
\hline \multirow[b]{2}{*}{ Patient } & \multicolumn{3}{|c|}{ Initial } & \multicolumn{3}{|c|}{ Metabolic acidosis } \\
\hline & $\begin{array}{l}\text { Arterial } \\
\text { pH }\end{array}$ & $\begin{array}{l}\text { Blood } \\
\text { pressure }\end{array}$ & $\begin{array}{l}\text { Pressor } \\
\text { dose }\end{array}$ & $\begin{array}{l}\text { Arterial } \\
\text { pH }\end{array}$ & $\begin{array}{l}\text { Blood } \\
\text { pressure }\end{array}$ & $\begin{array}{l}\text { Pressor } \\
\text { dose }\end{array}$ \\
\hline \multicolumn{6}{|c|}{$\underset{\min }{\operatorname{m\mu g} / \mathrm{kg} /}$} & $\underset{\min }{\operatorname{m\mu g} / \mathrm{kg} /}$ \\
\hline \multicolumn{7}{|c|}{ Before and after intake of ammonium chloride } \\
\hline $\begin{array}{r}4 \\
5 \\
6 \\
40\end{array}$ & $\begin{array}{l}7.39 \\
7.41 \\
7.41 \\
7.37\end{array}$ & $\begin{array}{l}115 / 70 \\
120 / 65 \\
100 / 70 \\
165 / 100\end{array}$ & $\begin{array}{l}7.8 \\
7.9 \\
9.3 \\
1.1\end{array}$ & $\begin{array}{l}7.28 \\
7.31 \\
7.33 \\
7.24\end{array}$ & $\begin{array}{l}120 / 70 \\
115 / 70 \\
110 / 70 \\
135 / 28\end{array}$ & $\begin{array}{l}7.8 \\
7.9 \\
9.5 \\
2.6\end{array}$ \\
\hline \multicolumn{7}{|c|}{ During and after intake of Shohl's solution } \\
\hline $\begin{array}{l}62 \\
63 \\
65\end{array}$ & $\begin{array}{l}7.36 \\
7.28 \\
7.35\end{array}$ & $\begin{array}{l}190 / 110 \\
210 / 90 \\
200 / 100\end{array}$ & $\begin{array}{l}4.1 \\
2.5 \\
4.6\end{array}$ & $\begin{array}{l}7.28 \\
7.21 \\
7.19\end{array}$ & $\begin{array}{l}180 / 115 \\
215 / 90 \\
230 / 110\end{array}$ & $\begin{array}{l}4.4 \\
2.9 \\
6.0\end{array}$ \\
\hline
\end{tabular}


TABLE IV

Comparison of pressor doses of angiotensin and l-norepinephrine

\begin{tabular}{|c|c|c|c|c|c|c|}
\hline \multirow[b]{3}{*}{ Patient } & \multirow[b]{3}{*}{ No. } & \multicolumn{4}{|c|}{ Pressor dose } & \multirow{3}{*}{$\begin{array}{c}\text { Ratio } \\
\text { Angiotensin: } \\
\text { norepinephrine }\end{array}$} \\
\hline & & \multicolumn{2}{|c|}{ Angiotensin } & \multicolumn{2}{|c|}{$l$-Norepinephrine } & \\
\hline & & Mean $\pm \mathrm{SD}$ & $\mathrm{p}^{*}$ & Mean $\pm \mathrm{SD}$ & $\mathrm{p}^{*}$ & \\
\hline & & $\operatorname{m\mu g} / \mathrm{kg} / \min$ & & $\mathrm{m \mu g} / \mathrm{kg} / \mathrm{min}$ & & \\
\hline Normotensive & 9 & $7.5 \pm 1.5$ & & $90.1 \pm 27.1$ & & $1: 12.0$ \\
\hline Essential hypertension & 6 & $3.4 \pm 1.1$ & $<0.001$ & $56.4 \pm 16.5$ & $<0.05$ & $1: 16.6$ \\
\hline Malignant hypertension & 5 & $19.9 \pm 5.6$ & $<0.001$ & $126.0 \pm 33.0$ & $<0.1$ & $1: 6.3$ \\
\hline Cirrhosis with ascites & 3 & $18.3 \pm 3.5$ & $<0.001$ & $99.0 \pm 13.5$ & $>0.5$ & $1: 5.4$ \\
\hline Renovascular hypertension & 6 & $8.4 \pm 1.2$ & $>0.5$ & $64.4 \pm 12.3$ & $<0.05$ & $1: 7.7$ \\
\hline
\end{tabular}

* Significance of the difference between the patient groups and the normotensive group.

Comparison of the pressor doses of angiotensin and l-norepinephrine

Four normotensive subjects were studied before and after the administration of chlorothiazide for 4 days. Initially, the mean pressor dose of angiotensin was $6.8 \pm 1.0 \mathrm{~m} \mu \mathrm{g}$ per $\mathrm{kg}$ per minute, the mean pressor dose of $l$-norepinephrine, 106 $\pm 23 \mathrm{~m} \mu \mathrm{g}$ per $\mathrm{kg}$ per minute, a ratio of $1: 15.6$. The infusion of $250 \mathrm{ml}$ normal saline decreased the pressor dose of angiotensin by $49 \%$ to 3.5 $\pm 1.1 \mathrm{~m} \mu \mathrm{g}$ per $\mathrm{kg}$ per minute $(\mathrm{p}=<0.01)$, and of $l$-norepinephrine by only $31 \%$, to $74 \pm 25 \mathrm{~m} \mu \mathrm{g}$ per kg per minute $(\mathrm{p}=<0.2)$. After chlorothiazide and an average weight loss of $1.1 \mathrm{~kg}$, the mean pressor dose of angiotensin increased $133 \%$, to $15.9 \pm 4.6 \mathrm{~m} \mu \mathrm{g}$ per $\mathrm{kg}$ per minute $(\mathrm{p}=$ $<0.02$ ), whereas the mean pressor dose of $l$ norepinephrine increased only $51 \%$ to $160 \pm 46$ $\mathrm{m} \mu \mathrm{g}$ per $\mathrm{kg}$ per minute $(\mathrm{p}=<0.2)$, a ratio of $1: 10.1$. After the rapid infusion of $500 \mathrm{ml}$ normal saline, the mean pressor dose of both decreased to near the initial control level, angiotensin to $5.5 \pm 1.9 \mathrm{~m} \mu \mathrm{g}$ per $\mathrm{kg}$ per minute, $l$ norepinephrine to $111 \pm 36 \mathrm{~m} \mu \mathrm{g}$ per $\mathrm{kg}$ per minute.

Comparative studies were done on some of the patients described in the preceding sections. As shown in Table IV, the changes from the level of the normotensive group in the pressor dose of angiotensin were much greater than the changes in the pressor dose of $l$-norepinephrine in the patients with essential hypertension, malignant hypertension, or cirrhosis. The decrease in the pressor dose of angiotensin in patients with essential hypertension was greater than the decrease of $l$-norepinephrine. The increase in the pressor dose of angiotensin in patients with malignant hypertension or cirrhosis with ascites was markedly greater than the increase of $l$-norepinephrine. Patients with renovascular hypertension also required proportionately more angiotensin than $l$-norepinephrine.

\section{Discussion}

A hypothesis for the control of the level of endogenous angiotensin has been proposed ( 7 , 8). According to this hypothesis, a decrease in effective arterial blood volume produces a decrease in renal arterial pulse pressure or the degree of stretch within the renal afferent arteriole and thereby stimulates the juxtaglomerular apparatus to secrete renin. Renin causes the release of angiotensin, which stimulates the secretion of aldosterone from the adrenal cortex. This in turn increases the renal tubular reabsorption of sodium, thereby increasing the blood volume and the blood flow to the kidney, resulting in an increase in the stretch within the renal afferent arterioles. The release of renin from the juxtaglomerular apparatus is dampened, and the level of circulating angiotensin decreases. This hypothesis implies that changes in the level of endogenous, circulating renin are reflected by changes in the level of endogenous angiotensin (9), and the two terms may, in this sense, be used interchangeably.

The plasma levels of renin have been shown to be decreased in subjects on a high salt diet and increased in subjects on a low salt diet (10). Measurements have not been reported for patients with pathological conditions included in the initial part of this study. However, patients 
with primary aldosteronism have an expanded plasma volume and should, therefore, have low levels of endogenous renin and angiotensin. $\mathrm{Pa}$ tients with cirrhosis who are accumulating ascites and subjects depleted of salt by diuretics should have decreased effective arterial blood volumes and, thereby, increased levels of endogenous renin and angiotensin. Dogs with a shrunken arterial blood volume secondary to constriction of the thoracic vena cava have been shown to have increased levels of angiotensin-like activity in their thoracic duct lymph (1).

The results of the initial part of this study suggest that the degree of responsiveness to the pressor effect of exogenous angiotensin may at least in part reflect the level of endogenous renin and angiotensin. In patients whose effective arterial blood volume is expanded because of primary aldosteronism or the rapid infusion of saline and who should, therefore, have low levels of endogenous angiotensin, little angiotensin was required for a pressor response. In patients whose effective arterial blood volume is shrunken because of the rapid accumulation of ascites, the deprivation of dietary sodium, or a diuresis induced with chlorothiazide, and who should, therefore, have high levels of endogenous angiotensin, more angiotensin was required for a pressor response.

These changes with angiotensin were in general qualitatively similar to but quantitatively more impressive than those observed with $l$-norepinephrine. If these changes were related entirely to nonspecific variations in responsiveness to all pressor agents, the changes might still be quantitatively different. However, the much more striking variations in responsiveness to angiotensin in various situations where endogenous levels of angiotensin are altered suggest that the pressor response to angiotensin may actually reflect endogenous levels of renin and angiotensin.

Changes in responsiveness to $l$-norepinephrine similar to those observed in this study have been observed after intake of chlorothiazide (11), salt deprivation (12), saline infusion (11), and in hypertension, both essential, in man (13), and renovascular, in animals (14). But the greater changes observed with angiotensin may reflect more than these presumably nonspecific alterations. Perhaps the decreased responsiveness to angiotensin in patients with presumably increased endogenous levels of renin and angiotensin is comparable to that noted in animals after repeated administration (15) or with experimentally induced elevations (16) of these substances. In keeping with the observation that patients with renovascular hypertension are less sensitive to angiotensin but are as sensitive to $l$-norepinephrine as are patients with essential hypertension is the experimental evidence that after the administration of renin the pressor response to renin or angiotension is blunted, but the pressor response to $l$-norepinephrine is not $(17,18)$.

This indirect evidence, of course, does not prove that the pressor response to antiotensin is a reliable estimate of the level of endogenous angiotensin, particularly in patients with essential hypertension. Their increased sensitivity to angiotensin is similar to that noted for various pressor substances (19) and may be related to the decreased size of the vascular lumen (20) or the higher initial blood pressure (21).

Nonetheless, this heightened sensitivity to the pressor effect of angiotensin in patients with essential hypertension or hypertension associated with chronic renal disease is to be contrasted with the decreased sensitivity in most patients with malignant hypertension or renovascular hypertension. In patients with malignant hypertension, the lessened responsiveness is not simply a reflection of the height of the blood pressure or the presence of renal insufficiency, since patients with equally high blood pressure or equally severe renal insufficiency who did not have malignant hypertension had an increased responsiveness. This decreased sensitivity may reflect high endogenous levels of angiotensin, since the renal ischemia that occurs as a consequence of the necrotizing arteriosclerosis of malignant hypertension should be a continuous stimulus to the release of renin and the maintenance of high levels of circulating angiotensin. Elevated levels have been demonstrated in such patients (22).

A similar mechanism may explain the lessened sensitivity to exogenous angiotensin noted in patients with renovascular hypertension, all of whom required a greater amount of angiotensin to induce a pressor response than did any of the patients with essential hypertension. Only one of the nine patients with renal arterial narrowing 
had malignant or rapidly accelerating hypertension, so that the insensitivity to angiotensin cannot be due to the consequences of the hypertension per se. Increased levels of circulating angiotensin would be expected in these patients if the narrowing of the renal artery caused a decreased stretch within the afferent arterioles and, thereby, a continuous stimulus to the release of renin. Increased levels of renin and angiotensin have been found in both animals (4) and humans (23) with renovascular hypertension.

In comparison with patients with essential hypertension or hypertension in association with chronic renal disease, an increased amount of angiotensin II was also needed to induce a pressor response in the two patients with hypertension in the active phase of acute glomerulonephritis and in the one patient with coarctation of the aorta. Increased levels of endogenous angiotensin may be present in patients with these diseases. The glomerular injury of acute nephritis may also involve the juxtaglomerular apparatus and cause the release of increased amounts of renin. With coarctation, the stretch within the renal arterioles may be decreased.

The infusion of angiotensin was repeated after relief of the hypertension and the removal of the cause of the presumably increased levels of circulating angiotensin II in patients with these latter three diseases, by surgery in the cases of renovascular hypertension and coarctation, and by healing of the active lesion in acute glomerulonephritis. In all instances the amount of angiotensin required to induce a pressor response fell. This further supports the assumption that the sensitivity to exogenous angiotensin may reflect the level of circulating endogenous angiotensin.

Regardless of the true relationship of the pressor response to exogenous angiotensin to the actual level of endogenous angiotensin, the results of our study suggest that this simple procedure may have clinical usefulness. If the separation between essential hypertension, hypertension due to chronic renal disease, and primary aldosteronism on the one hand, and renovascular hypertension on the other, is upheld with a larger group of patients, the procedure may be a rapid screening test for the differential diagnosis of these diseases. Even so, the procedure as here described would not identify those patients with malignant hyper- tension who have remediable lesions, since most patients with malignant hypertension from whatever cause will probably have a decreased responsiveness.

\section{Summary}

The sensitivity to the pressor action of synthetic angiotensin has been measured in humans under a variety of experimental and pathological conditions where the levels of endogenous angiotensin have either been shown or are presumed to be altered. The studies demonstrate that subjects with presumably low levels of endogenous angiotensin are more sensitive to the pressor effect of exogenous angiotensin; subjects with presumably high levels are less sensitive. The changes in sensitivity to angiotensin are greater than to $l$-norepinephrine.

Patients with malignant or renovascular hypertension are less sensitive to the pressor effect of angiotensin than are patients with essential hypertension, hypertension associated with chronic renal parenchymal disease, or primary aldosteronism. This simple procedure may have clinical usefulness in the differential diagnosis of renovascular hypertension.

\section{Acknowledgments}

The authors express their appreciation to Dr. Jock Graeme of the Ciba Pharmaceutical Co., Summit, N. J., for the generous supply of synthetic angiotensin and to the many physicians who referred patients for study.

\section{References}

1. Davis, J. O. The role of the adrenal cortex and the kidney in the pathogenesis of cardiac edema. Yale J. Biol. Med. 1963, 35, 402.

2. Laragh, J. H. Interrelationships between angiotensin, norepinephrine, epinephrine, aldosterone secretion, and electrolyte metabolism in man. Circulation 1962, 25, 203.

3. Johnston, C. I., and A. D. Jose. Reduced vascular response to angiotensin II in secondary hyperaldosteronism. J. clin. Invest. 1963, 42, 1411.

4. Gollan, F., E. Richardson, and H. Goldblatt. Hypertensin in the systemic blood of animals with experimental renal hypertension. J. exp. Med. 1948, 88, 389.

5. Kaplan, N. M. Primary aldosteronism with malignant hypertension. New Engl. J. Med. 1963, 269, 1282.

6. Bancroft, H. Introduction to Biostatistics. New York, Hoeber-Harper, 1957, p. 172. 
7. Tobian, L. Relationship of juxtaglomerular apparatus to renin and angiotensin. Circulation 1962, 25, 189.

8. Davis, J. O. The control of aldosterone secretion. Physiologist 1962, 5, 65.

9. Page, I. H., and F. M. Bumpus. Angiotensin. Physiol. Rev. 1961, 41, 331.

10. Brown, J. J., D. L. Davies, A. F. Lever, and J. I. S. Robertson. Influence of sodium loading and sodium depletion on plasma-renin in man. Lancet 1963, 2, 278.

11. Wanko, A., and E. Freis. Altered vascular responsiveness following chlorothiazide or mercurial diuresis in normotensive subjects (abstract). Circulation 1958, 18, 792 .

12. Raab, W., R. J. Humphreys, N. Makous, R. DeGrandpré, and W. Gigee. Pressor effects of epinephrine, norepinephrine and desoxycorticosterone acetate (DCA) weakened by sodium withdrawal. Circulation 1952, 6, 373.

13. Goldenberg, M., K. L. Pines, E. de F. Baldwin, D. G. Greene, and C. E. Roh. The hemodynamic response of man to nor-epinephrine and epinephrine and its relation to the problem of hypertension. Amer. J. Med. 1948, 5, 792.

14. Olsen, N. S., H. A. Schroeder, and E. M. Menhard. Effect of certain amines on the blood pressure of normotensive and hypertensive rats. Proc. Soc. exp. Biol. (N. Y.) 1950, 74, 581.
15. Taggart, J., and D. R. Drury. The action of renin on rabbits with renal hypertension. J. exp. Med. 1940, 71, 857.

16. Langford, H. G., C. McCaa, L. Sulya, and F. Alencon. Renin and angiotensin tachyphylaxis in relation to aldosterone secretion in renal hypertension. Fed. Proc. 1962, 21, 114

17. Conway, J. Vascular reactivity in experimental hypertension measured after hexamethonium. Circulation 1958, 17, 807.

18. Bock, K. D., and F. Gross. Renin and angiotensin tachyphylaxis. Circulat. Res. 1961, 9, 1044.

19. Doyle, A. E., J. R. E. Fraser, and R. J. Marshall. Reactivity of forearm vessels to vasoconstrictor substances in hypertensive and normotensive subjects. Clin. Sci. 1959, 18, 441.

20. Redleaf, P. D., and L. Tobian. The question of vascular hyper-responsiveness in hypertension. Cirulat. Res. 1958, 6, 185.

21. Aschheim, E., B. W. Zweifach, and M. B. Engelberg. Influence of intravascular pressure on vascular response to epinephrine. Proc. Soc. exp. Biol. (N. Y.) 1962, 111, 238.

22. Helmer, O. M. Presence of renin in plasma of patients with arterial hypertension. Circulation 1962, 25, 169.

23. Morris, R. E., Jr., P. A. Ransom, and J. E. Howard. Studies on the relationship of angiotensin to hypertension of renal origin (abstract). J. clin. Invest. 1962, 41, 1386. 